\title{
Nerve growth factor enhances Clara cell proliferation after lung injury
}

\author{
S.S. Sonar*, D. Schwinge*, A. Kilic*, A.Ö. Yildirim*, M.L. Conrad*, K. Seidler*, \\ B. Müller ${ }^{\#}$, H. Renz* and W.A. Nockher*
}

ABSTRACT: The lung epithelia facilitate wound closure by secretion of various cytokines and growth factors. Nerve growth factor (NGF) has been well described in airway inflammation; however, its likely role in lung repair has not been examined thus far.

To investigate the repair function of NGF, experiments were performed in vitro using cultured alveolar epithelial cells and in vivo using a naphthalene-induced model of Clara epithelial cell injury.

Both in vitro and in vivo experiments revealed airway epithelial cell proliferation following injury to be dependent on NGF and the expression of its receptor, tropomyosin-receptor-kinase A. Additionally, NGF also augmented in vitro migration of alveolar type II cells. In vivo, transgenic mice over-expressing NGF in Clara cells (NGFtg) did not reveal any proliferation or alteration in Clara cell phenotype. However, following Clara cell specific injury, proliferation was increased in NGFtg and impaired upon inhibition of NGF. Furthermore, NGF also promoted the expression of collagen I and fibronectin in vitro and in vivo during repair, where significantly higher levels were measured in re-epithelialising NGFtg mice.

Our study demonstrates that NGF promotes the proliferation of lung epithelium in vitro and the renewal of Clara cells following lung injury in vivo.

KEYWORDS: Airway epithelium, alveolar type II cells, Clara cells, lung injury and repair, naphthalene, nerve growth factor

$\mathrm{T}$ he mature healthy airway is a complex, yet fragile structure that is constantly exposed to inhaled environmental agents. Due to this close connection with the outside environment the lung is easily susceptible to damage; thus, injury and epithelial shedding are commonly described events in respiratory infections, asthma, chronic bronchitis and interstitial lung disease [1]. The lung has a remarkable capacity to facilitate repair through the use of specialised compartments with several distinctly functioning cell types. These cell types participate in a series of overlapping events to restore the respiratory epithelium. In the alveolar compartment of the lung, alveolar epithelial type II cells (AECII) are the putative progenitors of the alveolar epithelium and play an important role in the reepithelialisation of alveolar walls after lung injury $[2,3]$. Among the cell types lining the airway, the nonciliated bronchiolar cells (Clara cells) comprise the principal epithelial cell type of many species, including mice. Clara cells, which act as progenitors for goblet and ciliated epithelial cells are major contributors to the airway repair process $[4,5]$. In humans, Clara cells substantially contribute to the proliferation of tracheobronchial epithelium and have been described as an important cell population for the maintenance of the normal epithelium especially in the distal conducting airways [6].

Depending on the wound size and the degree of epithelial denudation, renewal of the damaged airway epithelium involves migration and proliferation of the residual epithelial cells from the adjoining, undamaged areas [7]. Expression of extracellular matrix (ECM) proteins in the provisional matrix are increased, and for Clara cells, factors like fibronectin and collagen I have been described to attract and provide adherence points for migration [8].

The Clara cell is uniquely susceptible to injury due to its capability to transform chemicals like naphthalene (NA) into toxic intermediates. NA is a polycyclic aromatic hydrocarbon commonly found in cigarette smoke and diesel exhaust and

\section{AFFILIATIONS}

*Dept of Clinical Chemistry and Molecular Diagnostics, University Hospital Marburg, and \# Laboratory of Respiratory Cell Biology, Dept of Internal Medicine, University Hospital Marburg, Germany.

CORRESPONDENCE

S.S. Sonar

Dept of Clinical Chemistry and

Molecular Diagnostics

Biomedical Research Center

Hans Meerweinstrasse

35043 Marburg

Germany

E-mail: sanchaitas@yahoo.co.in

Received:

Nov 032008

Accepted after revision:

Nov 042009

First published online:

Jan 142010 
is capable of inducing a highly dose-dependent and cell typeand site-selective toxicity $[9,10]$. The toxicity of NA is due to the metabolism of this compound by cytochrome P450 monooxygenases to a toxic intermediate that causes Clara cell swelling, vacuolisation, and exfoliation into the lumen of the airways $24 \mathrm{~h}$ after injury is initiated [11]. The use of NA in this study enabled us to investigate the ongoing repair processes following Clara cell specific injury in vivo.

Following injury, the mediators that drive airway epithelial repair may be derived from many sources. In addition to factors released from activated local immune cells [12], epithelial cells are also likely sources of autocrine and/or paracrine growth factors. One such mediator actively secreted by the airway epithelium is nerve growth factor (NGF), an eminent member of the neurotrophin growth factor family initially described to promote neuronal growth and survival [13]. Recently, the importance of NGF and its high affinity receptor, the tropomyosin-receptor-kinase A (TrkA) has been described in inflammatory diseases related to airway dysfunction $[14,15]$. Examples of this include NGF over-expression in the activated allergic bronchial [14], nasal [15] and airway epithelium as well as elevated epithelial NGF mediating eosinophil infiltration [16] and survival [17]. NGF is also expressed in the epithelia of other tissues, especially after activation via inflammation or during regenerative conditions [18-21]. Despite a few reports suggesting a role for NGF in wound healing elsewhere [22-24], its involvement in lung epithelial repair processes has not been investigated thus far.

The objective of this study was to examine the role of NGF in the repair of injured airway epithelia and our results highlight its contribution towards the proliferation of Clara airway epithelial cells in the lung following injury.

\section{METHODS \\ Mice}

6-8-week-old female C57BL/6 mice were obtained from Harlan Winkelmann (Borchen, Germany). Age-matched transgenic mice overexpressing NGF under the control of the lung-specific Clara-cell secretory protein promoter (NGFtg) were used [25]. All animal experiments were performed according to "The guidelines for the care and use of experimental animals" prepared and published by the Society for Laboratory Animal Sciences [26].

\section{Wound assay for lung epithelial cells}

LA4 murine lung alveolar epithelial cells (American Type Cul-

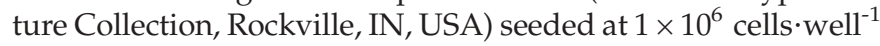
and supplemented with F12K Nutrient Mixture containing $15 \%$ FCS (Gibco, Carlsbad, CA, USA) were cultured until confluence onto 12-well plates. After overnight $(\mathrm{o} / \mathrm{n})$ serum starvation, monolayers were scratched from top to bottom using a $200 \mu \mathrm{L}$ pipette tip then incubated with either medium, medium containing recombinant human NGF $\left(\beta-\mathrm{NGF}, 100 \mathrm{ng} \cdot \mathrm{mL}^{-1}\right.$; R\&D systems, Minneapolis, MN, USA), polyclonal blocking antibodies to NGF (anti-NGF, $625 \mathrm{ng} \cdot \mathrm{mL}^{-1}$; Peprotech, Rocky Hill, NJ, USA), or immunoglobulin (Ig)G control (625 ng. $\mathrm{mL}^{-1}$; Sigma, St. Louis, MO, USA). All groups were incubated in medium containing $1 \%$ FCS. Medium with the accompanying supplements was changed every $24 \mathrm{~h}$. Wound size was measured in $\mu \mathrm{m}$ by light microscopy (Olympus, Hamburg, Germany) after wounding and every $24 \mathrm{~h}$ for $72 \mathrm{~h}$ using the Cell̂F imaging software program (Soft Imaging System $\mathrm{GmbH}$, Münster, Germany). At least 3-4 wounds of six LA4 cell monolayers were analysed.

\section{Proliferation of cultured lung epithelial cells}

Primary AECII were isolated according to the protocol provided in the supplementary material. $1 \times 10^{5} \mathrm{AECII}$ or LA4 cells ${ }^{*}$ ell $^{-1}$ were grown in 96 -well plates in triplicates. AECII were grown overnight in medium containing 10\% FCS followed by medium containing $0.1,1$ or $10 \%$ FCS for 24,48 and $72 \mathrm{~h}$. Proliferation of AECII cells was further assessed with $0.1 \%$ FCS containing medium, NGF, anti-NGF or control IgG for $72 \mathrm{~h}$ in concentrations described above for wound assay. For LA4 cells, $20 \mathrm{pmol} \cdot \mu \mathrm{L}^{-1}$ of NGF, TrkA or control siRNA (Qiagen, Hilden, Germany) were incubated with cells according to the manufacturer's instructions. Cell proliferation assays were performed using a BrdU (5-bromo-2'-deoxy-uridine) labelling kit according to the manufacturer's instructions (Roche, Mannheim, Germany). For further details, including primer sequences, see the supplementary material.

\section{In vitro migration assay using AECII}

AECII were assayed for NGF-induced migration using 24-well modified Boyden chamber (Falcon; BD, Franklin Lakes, NJ, USA) using transwell membranes ( $8-\mu \mathrm{m}$ pore size). The upper chamber contained $10^{5} \mathrm{AECII}$ in $500 \mu \mathrm{L}$ medium and the lower chamber contained $500 \mu \mathrm{L}$ of cell-free medium containing NGF $\left(100 \mathrm{ng} \cdot \mathrm{mL}^{-1}\right)$. Cells were incubated for $6 \mathrm{~h}$ at $37^{\circ} \mathrm{C}$ with $5 \% \mathrm{CO}_{2}$ after which inserts were removed and cells on the lower surface were counterstained with Diff-Quick (Dade, Behring, Germany) for $5 \mathrm{~min}$. An average of five $\times 100$ fields per insert was counted of five samples per group using light microscopy (Olympus, Hamburg, Germany). Migration is expressed as migrated cells per $\times 100$ field.

In vivo model of Clara cell injury and denudation using NA Wildtype (WT) or NGFtg control mice received intraperitoneal (i.p.) corn oil (Sigma Aldrich, Munich, Germany), WT or NGFtg mice undergoing Clara cell exfoliation received i.p NA (250 $\mathrm{mg} \cdot \mathrm{kg}^{-1}$, Sigma Aldrich Munich, Germany) dissolved in corn oil at day 0 (fig. S1a and b in the supplementary material). In additional groups, WT control mice and WT mice treated with NA also received either intranasal anti-NGF (anti-NGF, 2.5S, N 6655; Sigma-Aldrich) or intranasal control IgG (SigmaAldrich) at a concentration of $24 \mu \mathrm{g}$ at day 0, 3, 6 and 9 (fig. S1a and $\mathrm{b}$ in the supplementary material). A new set of mice also received BrdU in drinking water at a concentration of $1 \mathrm{mg} \cdot \mathrm{mL}^{-1}$ (water containing $1 \%$ glucose) from day 0 to day 10 (fig. S1a in the supplementary material). On days 1, 10 or 29 after treatment, bronchoalveolar lavage (BAL) was performed twice with $800 \mu \mathrm{L}$ of ice-cold PBS plus protease inhibitor mix (Roth, Karlsruhe, Germany) and whole lungs were removed for histological, mRNA and protein analysis.

\section{NGF ELISA}

NGF ELISA (Promega, Madison, WI, USA) was performed according to the manufacturer's instructions with cell free culture supernatants of six LA4 cell monolayers (with and without wound at 6, 12, 24, 48 and $72 \mathrm{~h}$ ) and BAL Fluid (BALF) of WT and NGFtg animals (control and NA treated at days 10 
and 29). Plates were read in a microplate autoreader (Tecan, Salzburg, Austria) at $405 \mathrm{~nm}$.

\section{Immunoblot analysis}

Total protein was extracted from LA4 cell monolayers, AECII and lung tissues of WT and NGFtg control and NA treated mice using the M-PER mammalian protein extraction kit (Thermo Scientific, Pierce, Bonn, Germany). Immunoblotting was performed as previously described [27] with NGF, TrkA (1:500, Santa Cruz Heidelberg, Germany), anti- $\beta$-actin monoclonal antibody (1:40,000; Sigma) and secondary peroxidiseconjugated antibodies (1:5000; Sigma). Immunoreactive protein bands were visualized with a chemiluminescent substrate (SuperSignal; Thermo Scientific, Pierce). Bands were scanned with the Kodak Image Station CF 450 and analysed using the Kodak 1D 3.5 imaging software. See the supplementary material for further details.

\section{RNA isolation, real-time PCR and analysis}

$5 \times 10^{5} \mathrm{AECII} \cdot \mathrm{mL}^{-1}$ were incubated in 24 -well plates with either anti-NGF $\left(625 \mathrm{ng} \cdot \mathrm{mL}^{-1}\right)$, control $\mathrm{IgG}\left(625 \mathrm{ng} \cdot \mathrm{mL}^{-1}\right)$, or recombinant human NGF $\left(100 \mathrm{ng} \cdot \mathrm{mL}^{-1}\right)$ for $24 \mathrm{~h}$. Total RNA was isolated from AECII or lung tissue using the RNeasy Mini Kit (Qiagen, Hilden, Germany). Quantitative PCR was performed using the QuantiTect SYBR ${ }_{\circledast}$ Green PCR Kit (Qiagen). Primers specific for collagen I, and fibronectin were used for real-time PCR. The mRNA copy numbers were compared and expressed relative to mouse ribosomal L32 as the housekeeping gene. See the supplementary material for further details.

\section{Immunohistochemistry}

Immunohistochemistry was performed on sectioned paraffin embedded lung tissues as described previously [28]. Primary antibody concentrations were; anti-Clara cell specific protein (CCSP) (diluted 1:3,000; courtesy of J. Klug, Justis-LiebigUniversität, Giessen, Germany); anti-fibronectin (diluted 1:1,000; Biozol, Eching, Germany), anti-collagen I (diluted 1:500; Biozol), sheep anti-BrdU (diluted 1:10; Biozol). Secondary biotinylated antibodies (Vector Laboratories, Burlingame, CA, USA) were diluted 1:400. Sections were analysed using light microscopy (Olympus Europa GmbH, Hamburg, Germany).

\section{Morphometric analysis of Clara cells and BrdU- incorporating proliferating cells}

Mouse lungs were fixed by airway instillation using $6 \%$ phosphate buffered paraformaldehyde at a pressure of $20 \mathrm{~cm}$ fluid column. Lung volume was determined by fluid displacement, and systemic uniform random samples of lung tissue were taken and processed according to standard methods [29]. The morphometric analysis for CCSP- and BrdU-positive cells was performed using a modified version of a previously described method [30]. Proximal and distal airways were counted in a blinded manner. CCSP-positive cells containing nuclear profiles and BrdU-positive nuclear profiles were counted. See online supplement for further details.

\section{Statistical analysis}

Statistical significance for normally distributed samples was analysed by using an unpaired t-test. Comparisons between more than two groups were made by one way ANOVA. A p-value
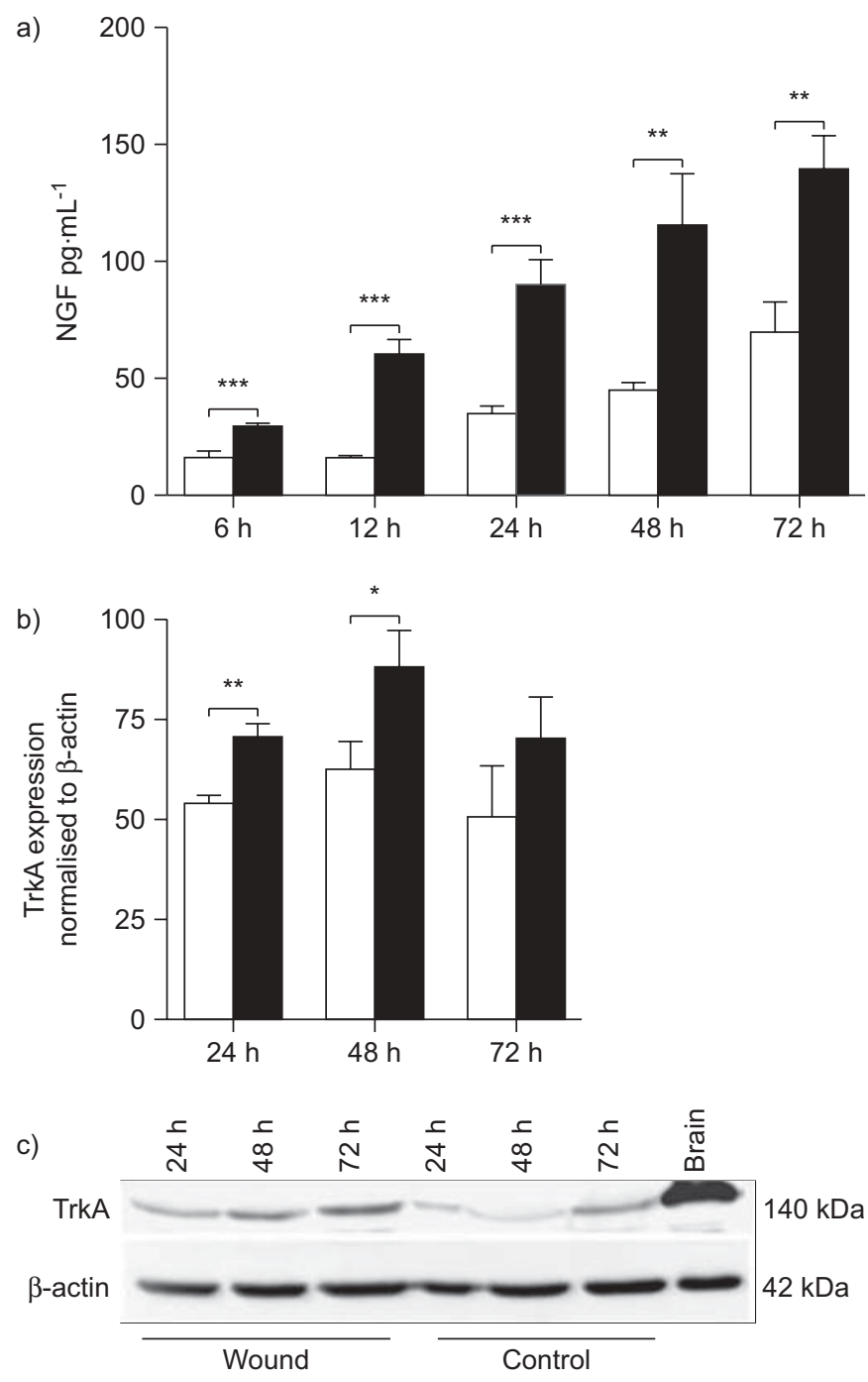

FIGURE 1. Production of nerve growth factor (NGF) and expression of TrkA in vitro after LA4 cell monolayer wounding. a) NGF production was measured by ELISA in unwounded control ( $\square$ ), and wounded (ם) LA4 cells at 6, 12, 24, 48 and $72 \mathrm{~h}$. b) The expression of TrkA was examined by quantifying intensity of bands normalised to $\beta$-actin by western blotting in control $(\square)$ and LA4 monolayers with wound ( $)$ at 24, 48 and 72 h. c) A representative blot showing expression of TrkA $(140 \mathrm{kDa})$ and $\beta$-actin (42 kDa) in wounded and control LA4 monolayers at 24, 48 and $72 \mathrm{~h}$ from the same experiment as in (b). Data are presented as mean \pm sem $(n=6)$ at each time point. $*: p<0.05 ; * *: p<0.01 ; * \star * ; p<0.001$.

of $<0.05$ was considered statistically significant. All numerical data are expressed as mean \pm SEM. Calculations were performed using Graph Pad prism software, version 3.02.

\section{RESULTS}

\section{NGF production and TrkA expression is increased in wounded lung epithelial cells in vitro}

The expression of NGF in lung epithelial cells was first examined in an in vitro wound assay model using murine LA4 cells. Wounding confluent monolayers of LA4 cells led to an increase in the expression of both NGF and its receptor, TrkA (fig. 1). NGF protein levels in wounded epithelial cells were significantly higher compared with nonwounded LA4 cells at 
a)
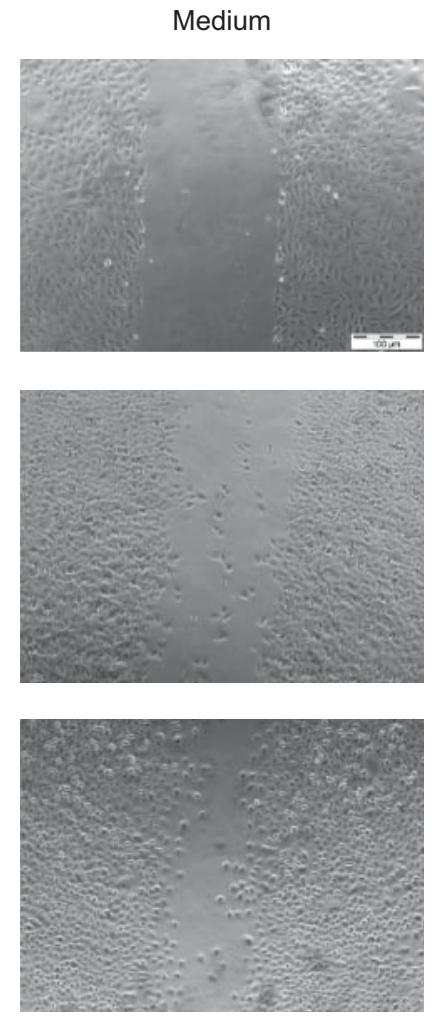

$48 \mathrm{~h}$

$72 \mathrm{~h}$

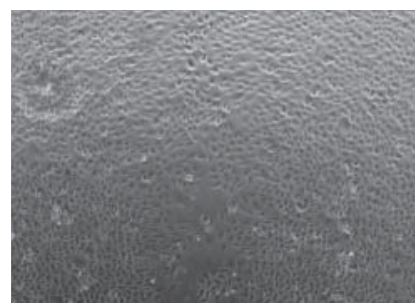

NGF
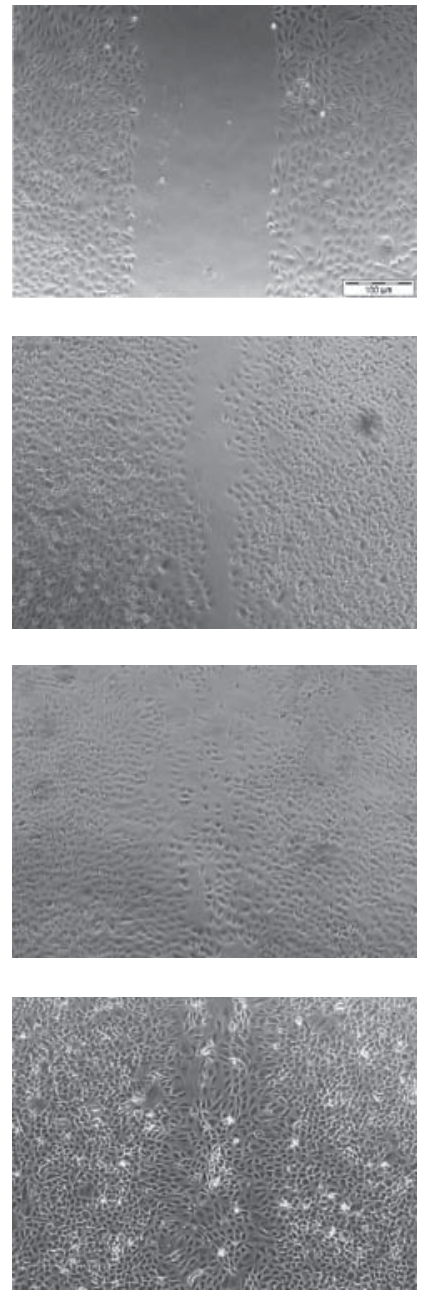

anti-NGF
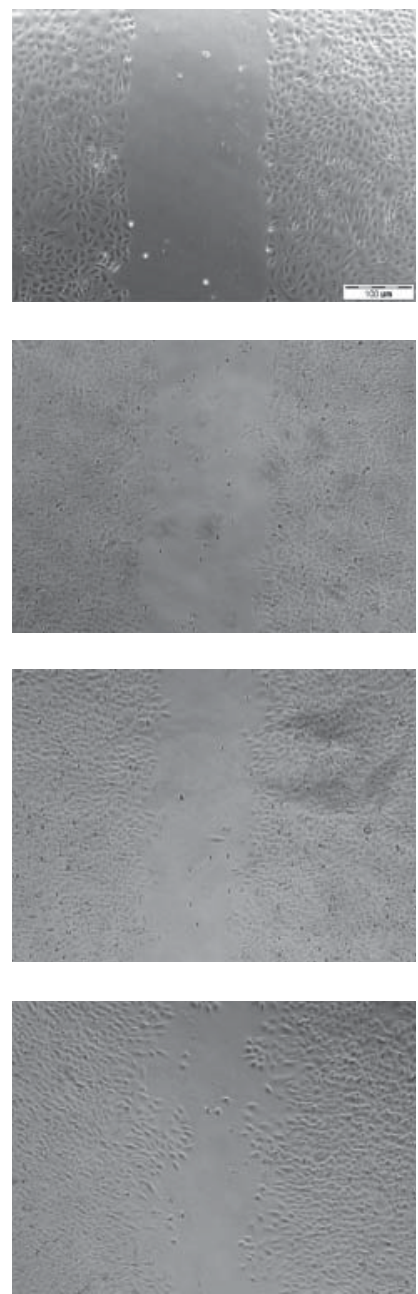

$\lg G$
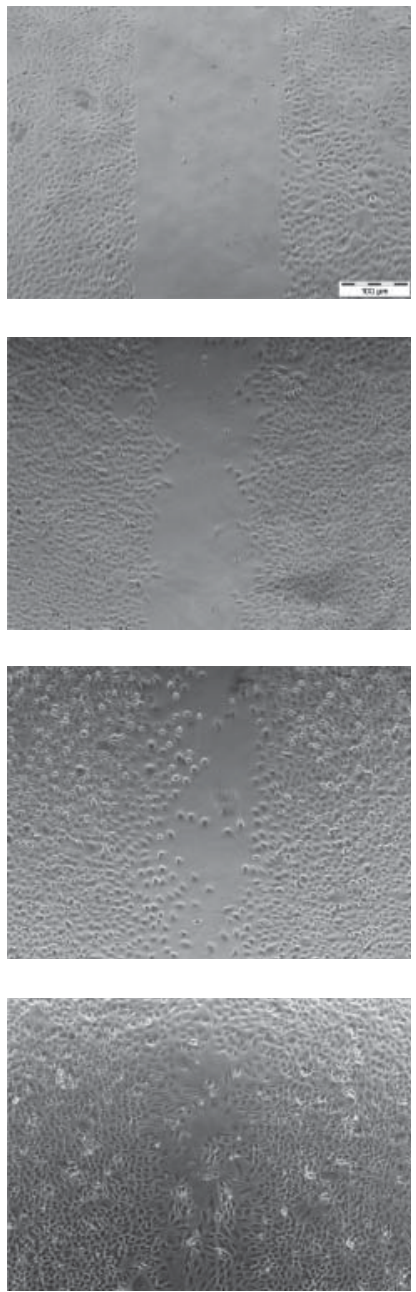

b)

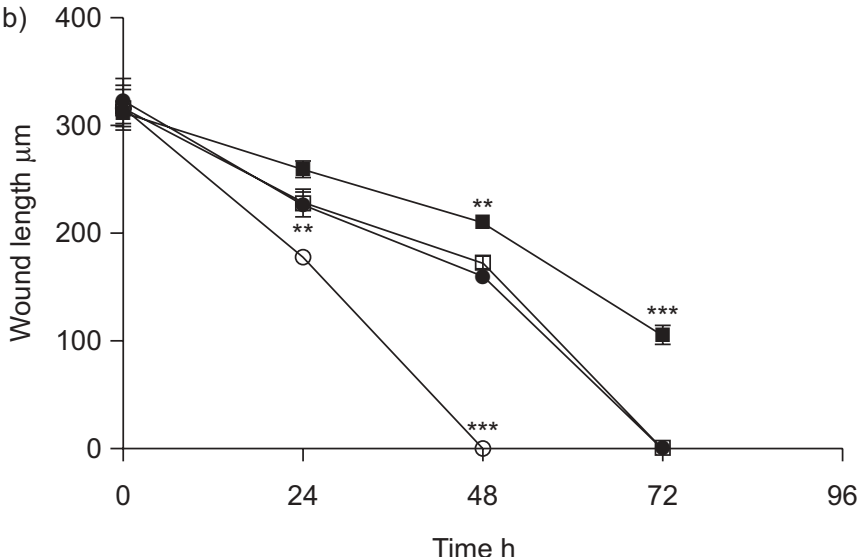

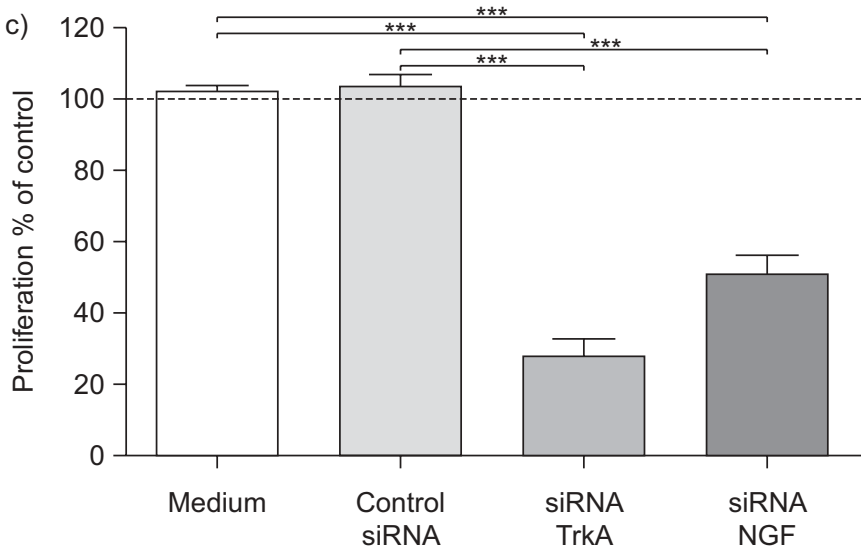

FIGURE 2. Nerve growth factor (NGF) regulates wound closure of LA4 cells in vitro. a, b) Confluent monolayers of LA4 cells were wounded and the kinetics of wound closure was monitored in monolayers grown in medium only (medium; $\square$ ), medium with recombinant NGF (NGF, O), immunoglobulin (Ig)G control (lgG, $\bullet$ ), or with anti-NGF (anti-NGF, - at ) a, 24, 48, and $72 \mathrm{~h}$. Wound closure was quantified by measuring wound length in $\mu \mathrm{m}$ across the wound. Statistical comparisons for NGF-stimulated and anti-NGF-treated groups were made to the medium only group. c) Cell proliferation was determined by measuring incorporation of BrdU (5-bromo-2'-deoxy-uridine) in DNA of proliferating LA4 cells. The rate of proliferation is represented relative to basal proliferation in the medium control where BrdU incorporation was taken as $100 \%$ ( $\cdots \cdots$. . TrkA ( $\square$ ) and NGF ( $\square$ ) were blocked by specific siRNA and compared to cells grown in the transfection assay medium $(\square)$ and a non-specific siRNA ( $\square$ ). Data are presented as mean $\pm \operatorname{SEM}(n=6)$ for each time point. ${ }^{* *}: \mathrm{p}<0.001$. Scale bars $=100 \mu \mathrm{m}$ for all panels. 

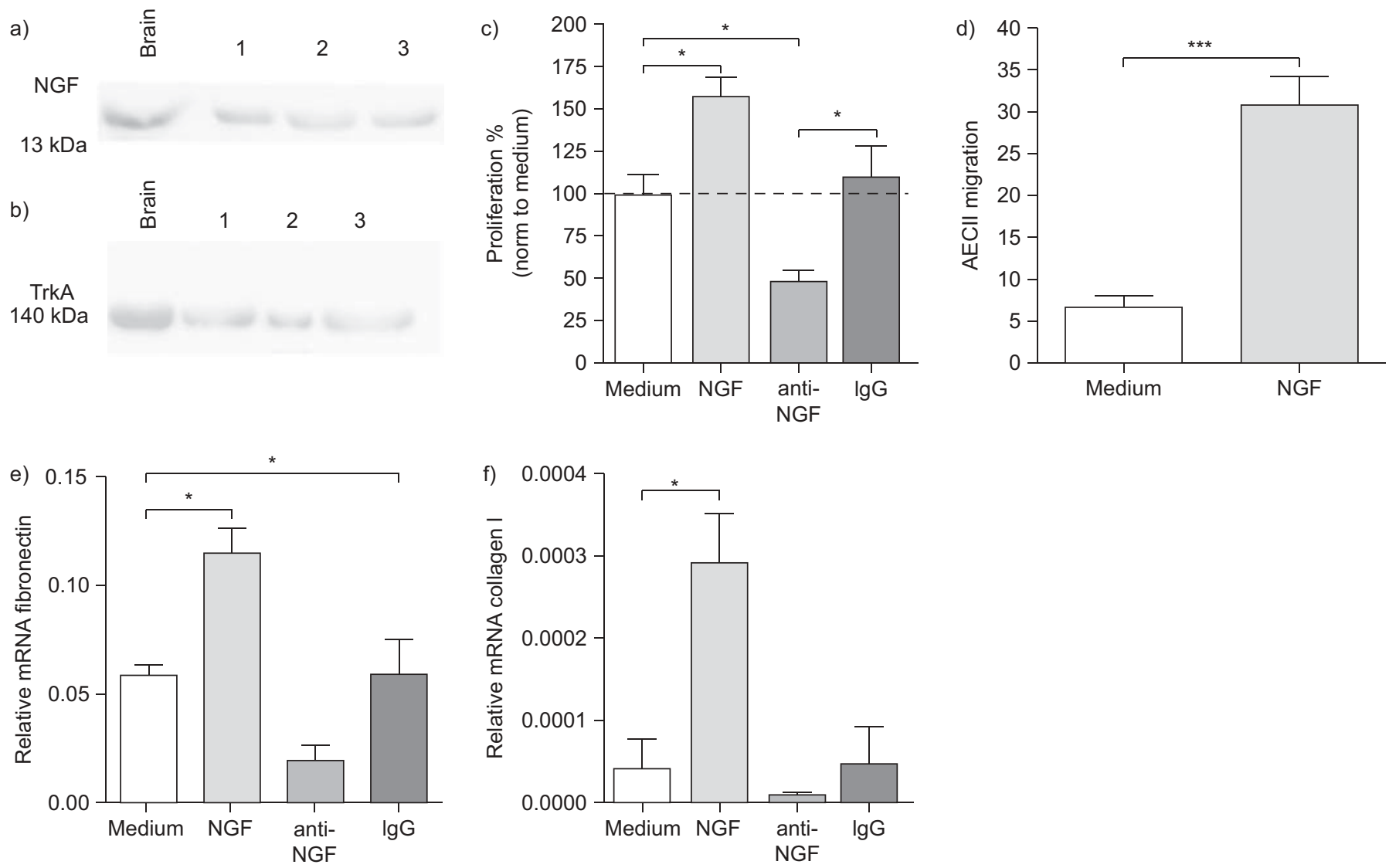

FIGURE 3. Nerve growth factor (NGF) regulates proliferation, migration and extracellular matrix mRNA expression of alveolar epithelial type II cells (AECII). a) NGF and b) TrkA protein expression by AECII. c) AECII proliferation analysed after $72 \mathrm{~h}$ incubation with either medium only or medium containing NGF, anti-NGF or control immunoglobulin (Ig)G. d) AECII migration analysed after $6 \mathrm{~h}$ incubation with medium or recombinant NGF. Migration is expressed as migrated cells per $\times 100$ field of view. Relative mRNA levels of e) fibronectin or f) collagen I in AECIl cells incubated for $24 \mathrm{~h}$ in either medium only or medium containing NGF, anti-NGF or control IgG. Data are presented as mean $\pm \operatorname{SEM}(n=6)$ copy number target gene per copy L32 (relative mRNA) for each group. ${ }^{*}: p<0.05 ;{ }^{* \star *}: p<0.001$.

all time points measured (fig. 1a). A progressive increase in NGF after wounding was observed until $72 \mathrm{~h}$, with elevated levels observed as early as $6 \mathrm{~h}$. NGF production also increased with time in the nonwounded cells, correlating with normal cell proliferation. Correspondingly, TrkA was upregulated at 24 and $48 \mathrm{~h}$ post wounding and was present in significantly higher amounts compared with nonwounded monolayers (fig. 1b). The increase in TrkA expression coincided with the increase of NGF in the supernatant (fig. 1a). These results indicate that autocrine NGF and TrkA are induced upon lung epithelial cell injury.

\section{NGF promotes wound closure and proliferation of epithelial cells in vitro}

To determine if the observed upregulation of NGF and its receptor has an effect on the closure of wounds, wounded monolayers of LA4 cells were incubated with either blocking antibodies to NGF (anti-NGF) or with exogenous NGF. Inhibition of NGF markedly delayed closure of wounds, whereas exogenous NGF protein significantly accelerated wound closure (fig. 2a and b). Control wounded monolayers incubated with control IgG antibodies or medium only had wounds of similar size (fig. 2a and b). In control monolayers, wound closure was achieved at $72 \mathrm{~h}$, whereas wounds failed to close in the anti-NGF treated groups even at $72 \mathrm{~h}$, (fig. 2a). In contrast, wounds incubated with NGF closed at an earlier time point of $48 \mathrm{~h}$. Since the proliferative effect of NGF is reported to be mediated by its high-affinity receptor TrkA, the effect of NGF and TrkA on the regulation of lung epithelial cell proliferation was also investigated in vitro. siRNA inhibition of NGF or TrkA knocked down the mRNA and protein levels to significantly lower levels compared to the medium control (fig. S2 in the supplementary material). Inhibition of TrkA and NGF with these siRNAs significantly decreased proliferation of LA4 epithelial cells by $\sim 75$ and $50 \%$ of medium control, respectively (fig. 2c). These results indicate that NGF and TrkA are important for the proliferation and repair of wounded lung epithelia in vitro.

\section{NGF mediates proliferation, migration and ECM expression by $A E C I I$}

After determining the important role of NGF in a lung epithelial cell line, we were interested to examine the effect of NGF and TrkA in primary AECII. NGF and TrkA were found to be expressed in primary AECII (fig. 3a and b). In order to test the role of NGF on primary AECII cell proliferation, we established an in vitro assay. A time and dose response for AECII proliferation in vitro at 24,48 and $72 \mathrm{~h}$ 
in $0.1 \%, 1 \%$ and $10 \%$ FCS concentration (fig. S3c in the supplementary material) revealed $72 \mathrm{~h}$ as the optimal time point to examine proliferation. NGF was seen to significantly influence proliferation at $0.1 \%$ FCS concentration. In line with our previous in vitro results using LA4 cells, NGF increased the proliferative capacity of AECII, whereas anti-NGF significantly downregulated proliferation compared with the medium and IgG control (fig. 3c). We also investigated the role of NGF in mediating migration, which is a critical event in wound repair. NGF was seen to strongly induce migration of AECII upon incubation with exogenous NGF (fig. 3d). Furthermore, the expression of ECM factors, such as collagen I and fibronectin were also investigated in vitro in primary cell cultures of AECII. The mRNA expression of fibronectin and collagen I was significantly increased upon incubation with exogenous NGF (fig. $3 e$ and $f$ ) and the inhibition of NGF led to a significant decrease in fibronectin mRNA expression (fig. 3e). These results imply that NGF actively promotes proliferation and migration of AECII, which are critical requisites for wound repair.

\section{NGF and TrkA are increased during repair of airway epithelia in vivo}

To examine the role of NGF in airway epithelium repair in vivo, we employed a NA induced model of Clara epithelial cell injury in the lung. Expression of NGF and TrkA was determined at 10 and 29 days post injury with NA in the BAL fluid and total lung protein of WT and NGFtg animals (fig. 4). In untreated NGFtg control mice, the baseline level of NGF was significantly higher due to the constitutive overexpression of NGF under the Clara cell specific-promoter compared to WT control animals (fig. 4a). Following injury with NA, WT animals showed a progressive upregulation of NGF which lasted until day 29 (fig. 4a). Conversely, NGF levels in the NGFtg animals declined after NA treatments at all time points compared to untreated NGFtg animals due to the NA induced loss of NGF over-expressing Clara cells. However, the amount of NGF in the NA treated NGFtg animals was significantly higher at all time points compared to NA treated WT animals. The over-expression of NGF in Clara cells had no effect on the total number of Clara cells lining the airways (data not shown) and the denudation of Clara cells $24 \mathrm{~h}$ after NA injury was found to be similar in NA treated WT (WT-NA) and NGFtg (NGFtg-NA) animals (fig. S4A in the supplementary material). Additionally, the number of exfoliated cells quantified in the BALF of both groups of mice was comparable (fig. S4b in the supplementary material).

To investigate the role of TrkA as a downstream target of NGF during the repair processes, its levels were quantified concomitantly in lung tissues. TrkA was found to be significantly upregulated at days 10 and 29 post Clara cell injury in the NGFtg animals compared with WT animals (fig. 4b).

These results suggest that NGF and its receptor, TrkA, are upregulated upon airway epithelial damage and their induction is maintained throughout the ongoing repair process.

\section{NGF promotes renewal of Clara cells}

We next tested the role of NGF in the renewal of Clara cells upon injury. Clara cells comprise a major epithelial cell population lining the murine bronchial airways. Following
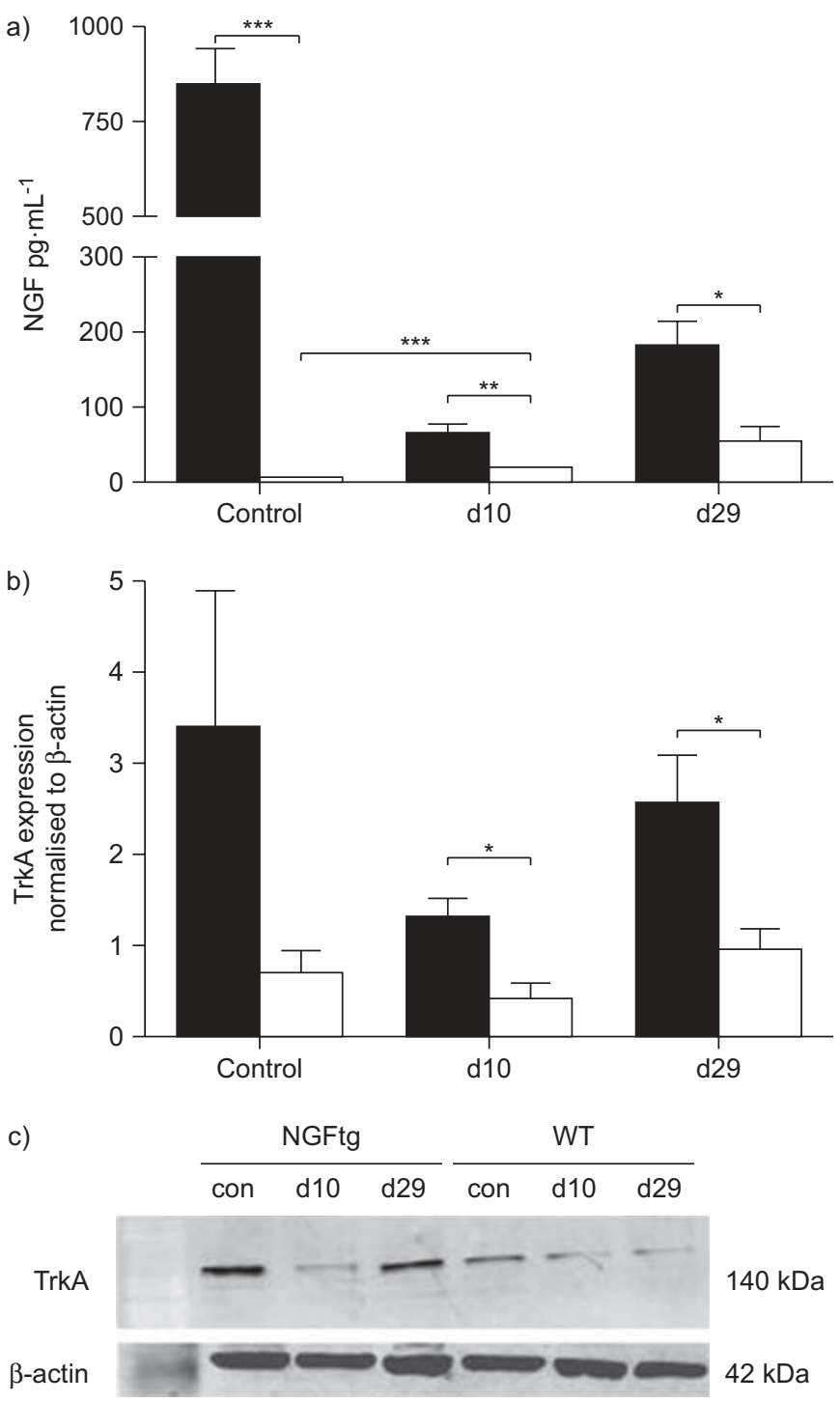

FIGURE 4. Expression of nerve growth factor (NGF) and TrkA in vivo following Clara cell lung injury. a) NGF levels in NGFtg ( $\square)$ and wildtype ( $\square$ ) animals without naphthalene (NA) treatment (control) and after NA treatment at day 10 and 29 (d10, d29). NGF expression was measured by ELISA in bronchoalveolar lavage. b) The expression of TrkA was quantified and represented as band intensity normalised to the housekeeping gene, $\beta$-actin. c) A representative blot showing expression of TrkA (140 kDa) and $\beta$-actin $(40 \mathrm{kDa})$ in control NGFtg and wild-type (WT) animals (control) and after NA treatment at day 10 and 29 (d10, d29) from the experiment is shown below the graph. Data are presented as mean \pm SEM $(n=6)$ for each group of mice. ${ }^{*}: p<0.05,{ }^{*}: p<0.01,{ }^{* *}: p<0.001$

NA treatment, Clara cells were denuded by day 1 (fig. 5a). At day 10, Clara cells in the airways had started reappearing around the airways in all groups treated with NA, as quantified by CCSP staining (fig. 5b). Mice treated with NA or NA and control IgG showed similar Clara cell numbers at day 10, with considerable portions of the airway already lined by Clara cells. In contrast, animals treated with NA and neutralising anti-NGF antibodies, had significantly lower counts of CCSP-positive cells lining the airway at day 10 , reappearing only sporadically around the airway epithelium (fig. 5). These results indicate 
a)
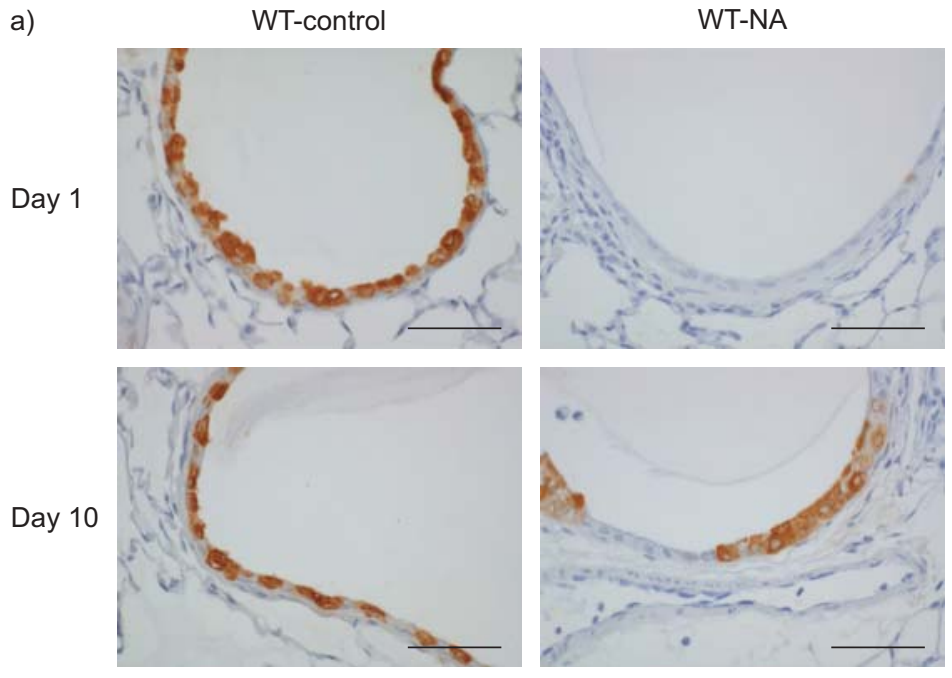

WT-anti-NGF-NA
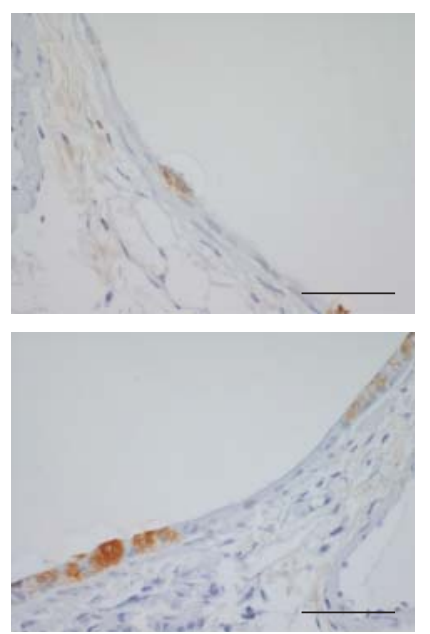

WT-IgG-NA
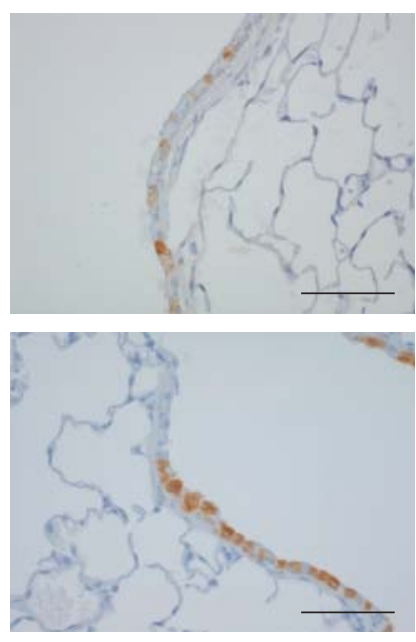

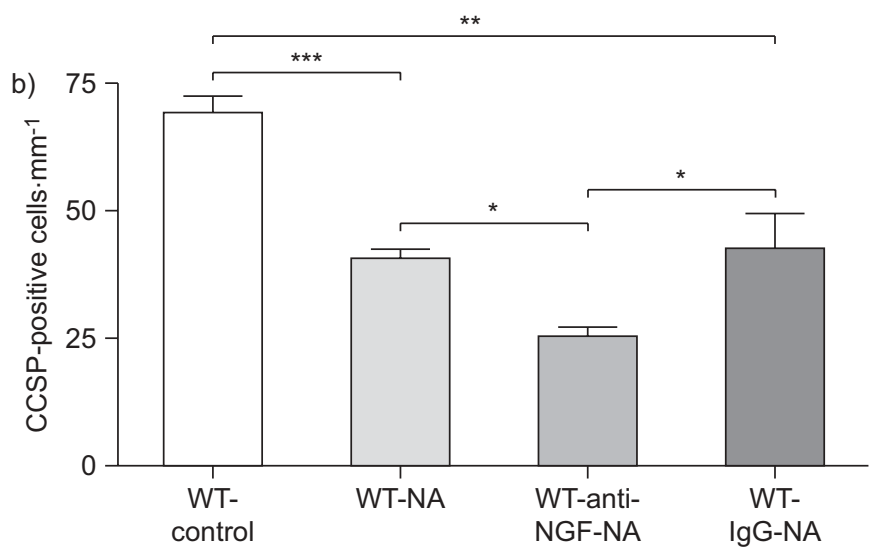

that NGF facilitates Clara cell renewal in vivo upon NAinduced injury.

\section{NGF induces collagen I and fibronectin mRNA expression upon NA induced Clara cell injury}

Cellular migration and proliferation critically depend on the adhesive interactions between cells and the underlying matrix. Also, considering that Clara cells show preferential adherence to collagen I and fibronectin, we utilised the NA model to examine the effect of NGF on the expression of these matrix molecules (fig. 6). Indeed, collagen I and fibronectin mRNA levels were significantly increased in lung homogenates of NGFtg animals at day 10 after NA exposure compared to untreated NGFtg control animals (fig. 6a and b). Moreover, the application of anti-NGF reduced the expression of collagen I in NA treated WT animals (fig. 6a). Immunohistochemical staining for collagen I and fibronectin corroborated the qPCR data and more intense collagen I and fibronectin staining underlying the epithelial layer was observed in the control and NA treated NGFtg animals compared with their respective controls (fig. $6 \mathrm{c}$ and d). The application of anti-NGF revealed relatively reduced staining for collagen I in NA-treated WT animals. These results suggest that NGF actively augments the expression of the ECM factors collagen I and fibronectin during repair processes in the lung.
FIGURE 5. Clara cell renewal. a) Intact Clara cells in corn oil treated wild-type (WT) control animals at day 1 and day 10 (WT-control) and after naphthalene (NA) treatment (WT-NA) with anti-nerve growth factor (NGF) (WT-anti-NGF-NA) or control immunoglobulin (Ig)G (WT-IgG-NA) antibodies. Clara cells were stained for Clara cell secretory protein (CCSP) as brown-coloured nonciliated columnar cells against the blue counter stain. Scale bars $=50 \mu \mathrm{m}$. b) Quantification of CCSP-positive cells per $\mathrm{mm}$ of the basement membrane at day 10 after NA treatment. Data are presented as mean $\pm \operatorname{SEM}(n=6)$ for each group of mice. $*: p<0.05,{ }^{* *}: p<0.01,{ }^{* * *}: p<0.001$

\section{NGF promotes proliferation of Clara cells in the lung}

After observing that NGF promotes Clara cell renewal as well as the expression of collagen I and fibronectin expression, we investigated the direct effect of NGF on epithelial cell proliferation by administration of BrdU in vivo (fig. S1b in the supplementary material). Quantification of BrdU-positive proliferating cells revealed lack of proliferation in the airways of untreated WT and NGFtg control animals, whereas all NA treated groups contained BrdU positive nuclei (fig. 7). Staining serial sections in parallel with BrdU and CCSP revealed proliferating Clara cells (fig. 7a). Injury and cell denudation was therefore shown to induce re-epithelialisation via increased Clara cell proliferation in the lung. Upon inhibition of NGF with anti-NGF antibody, significantly lower numbers of proliferating epithelial cells were observed, while application of a control IgG antibody showed no effect. In line with these results, NGFtg mice treated with NA exhibited the highest numbers of proliferating epithelial cells (fig. 7b). Together, these results show strong effects of NGF on Clara cell proliferation during repair of injured lung.

\section{DISCUSSION}

NGF and other members of the neurotrophin family were initially identified as neuronal growth and survival factors but are currently recognised to have biological activities in tissues 

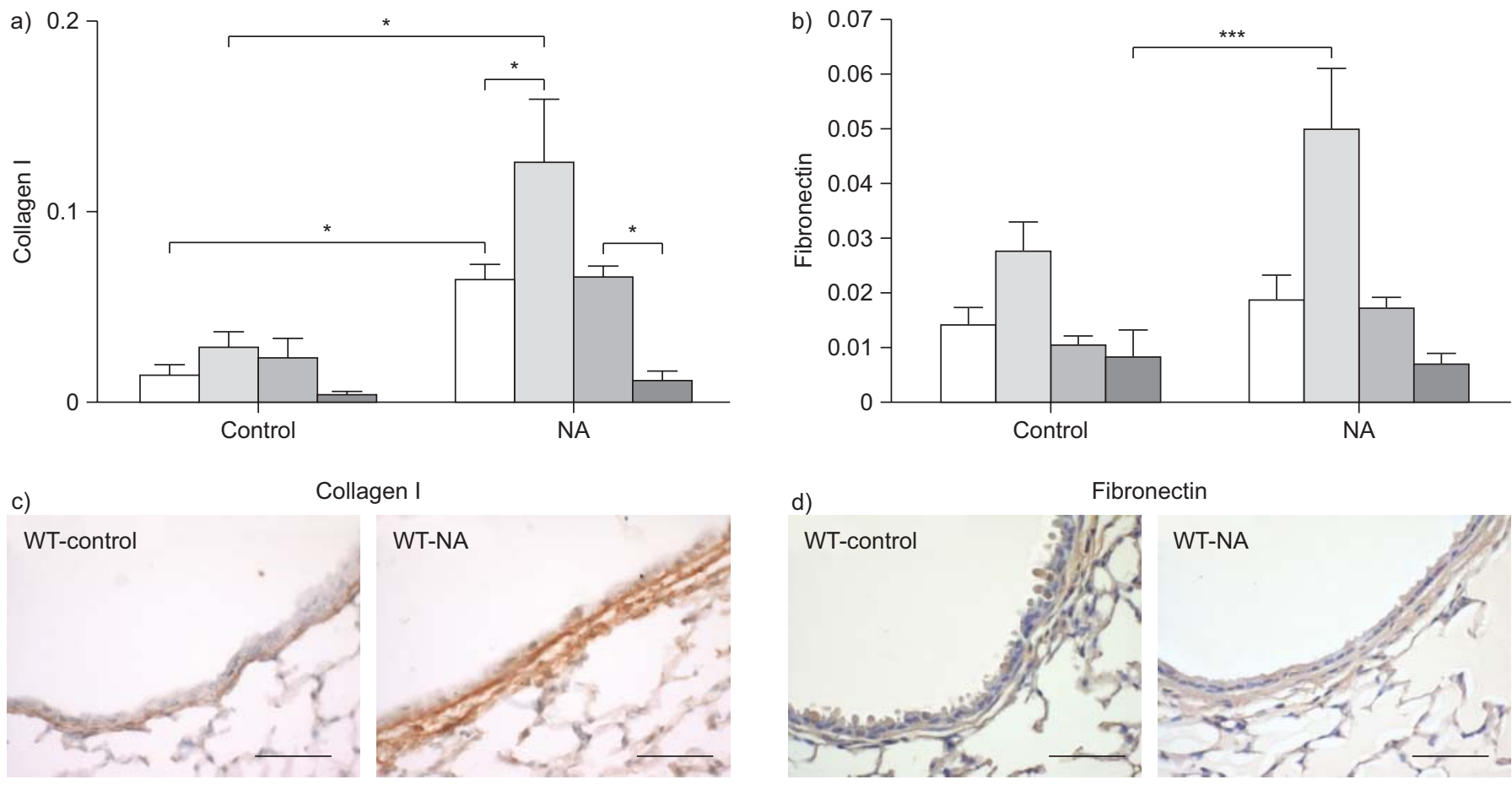

Fibronectin
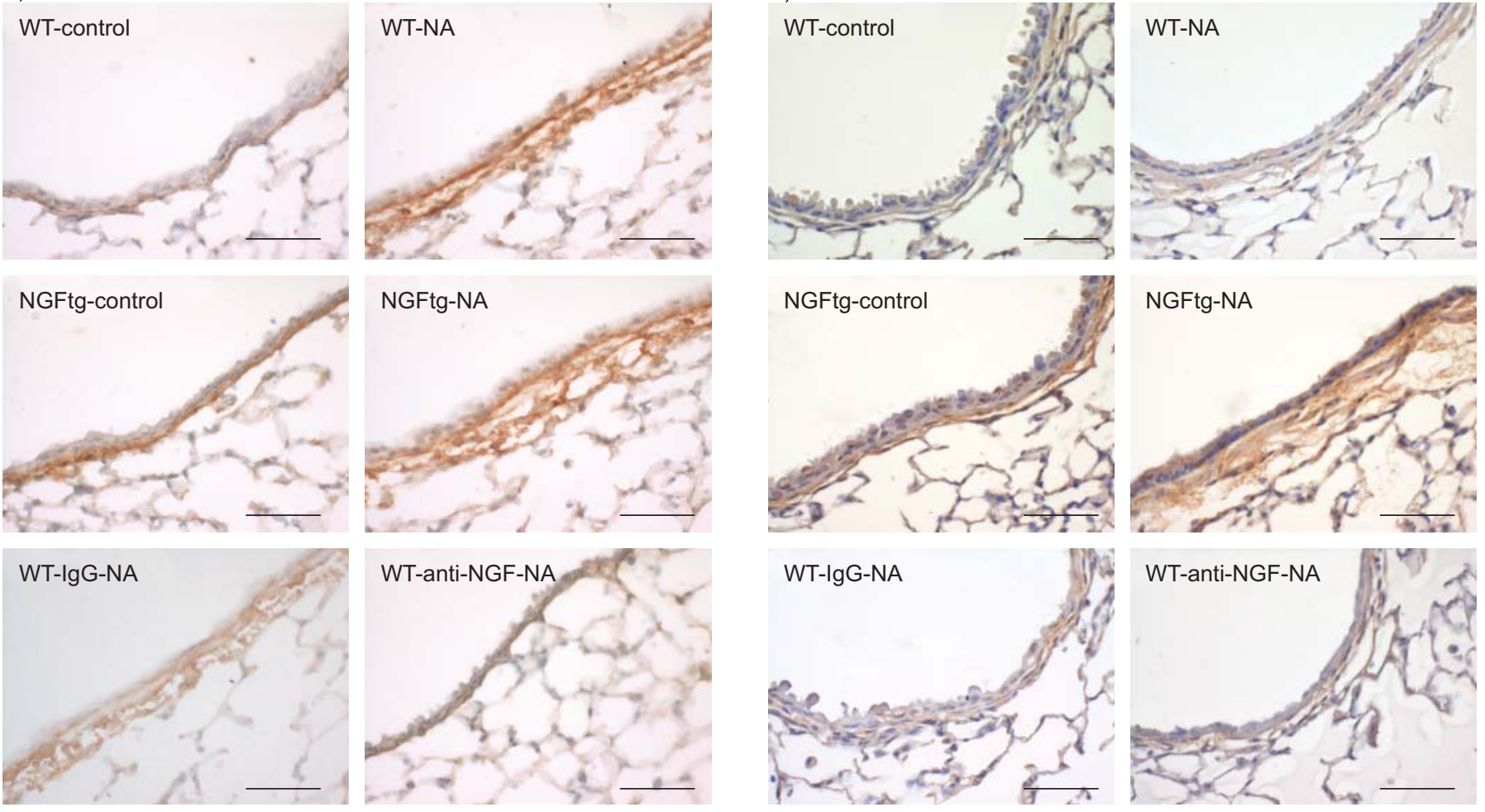

FIGURE 6. Modulation of collagen I and fibronectin expression by nerve growth factor (NGF). Relative mRNA levels of a) collagen I and b) fibronectin are shown. Data are expressed as copy number of target gene per copy L32 (relative mRNA). mRNA was analysed in wild-type (WT; $\square$ ), NGFtg ( $\square$ ), WT animals treated with immunoglobulin

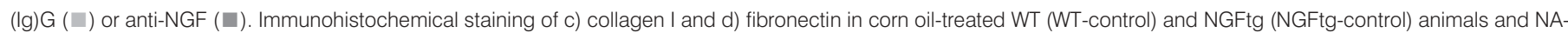
treated WT (WT-NA), with anti-NGF (WT-anti-NGF-NA) or with control IgG (WT-IgG-NA) and NA-treated NGFtg (NGFtg-NA) animals analysed at day 10. Scale bars=50 $\mu$ m. Data are presented as mean $\pm \operatorname{SEM}(n=6)$ for each group of mice. *: $p<0.05 ; * * *: p<0.001$.

outside the nervous system [31]. Various visceral epithelia are known to produce neurotrophins which were initially speculated to regulate tissue innervation [32] and autocrine functions of neurotrophins are increasingly being described. For example, NGF production is increased during inflammatory processes that are accompanied by epithelium damage in asthma [17, 33], infections [34] and sarcoidosis [35].

Previous reports have suggested the involvement of NGF in epithelial wound healing in other tissues. Topical application of NGF has been shown to accelerate wound closure and re-epithelialisation in surgical wounds of the skin [36] and the cornea [23]. Moreover, NGF is strongly produced at the site of the wounded skin and is increased in newly formed epithelial cells at the edge of the wound but not in the surrounding epidermal keratinocytes [37]. In the cornea, an increase in NGF was observed after epithelial injury and corneal epithelial cell expression of NGF and its receptor TrkA was observed [38]. When epithelial surfaces are injured, the normal response is to upregulate receptors for growth factors that drive proliferation and repair [39]. The purpose of the present study was to determine the function of NGF in facilitating proliferation of 
a)
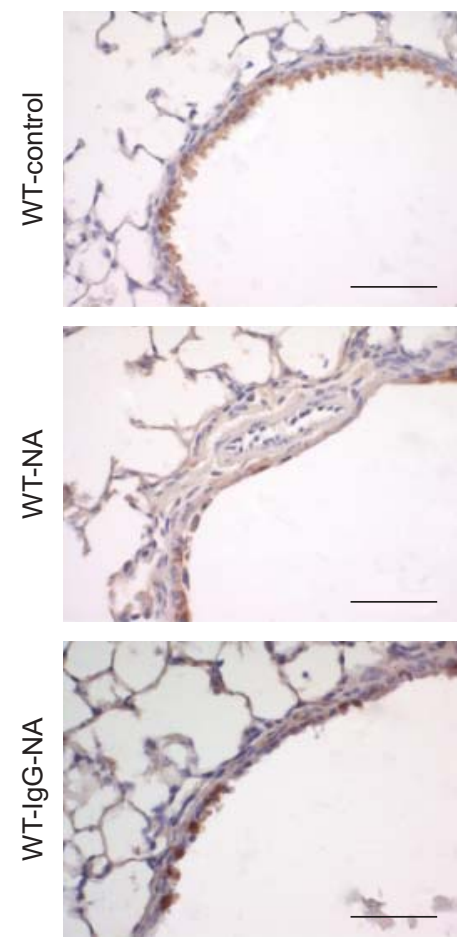

b)

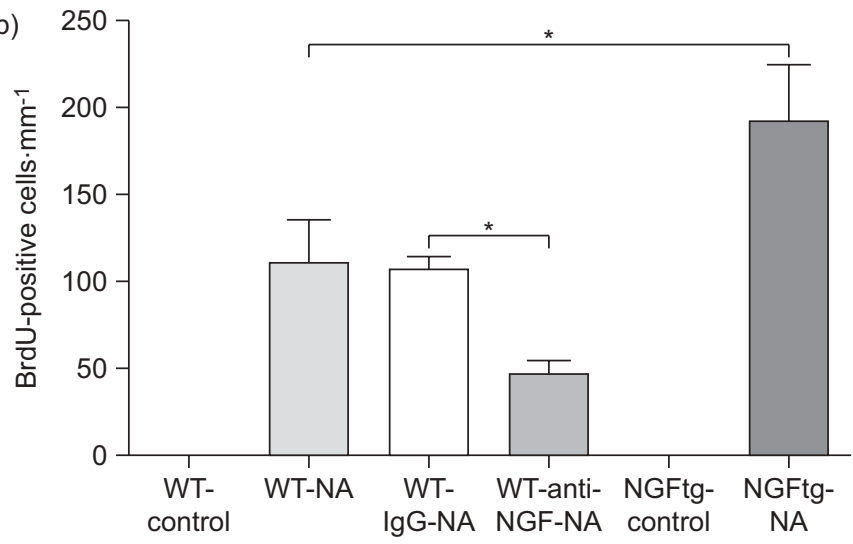

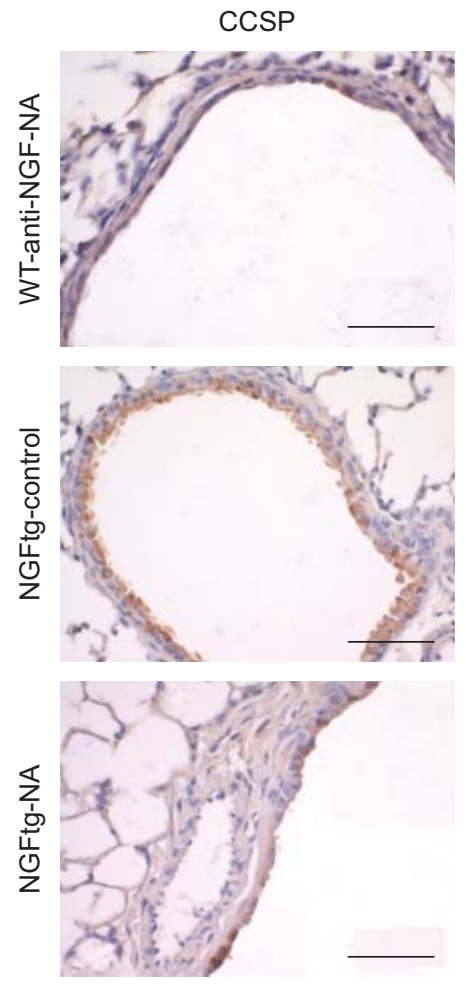
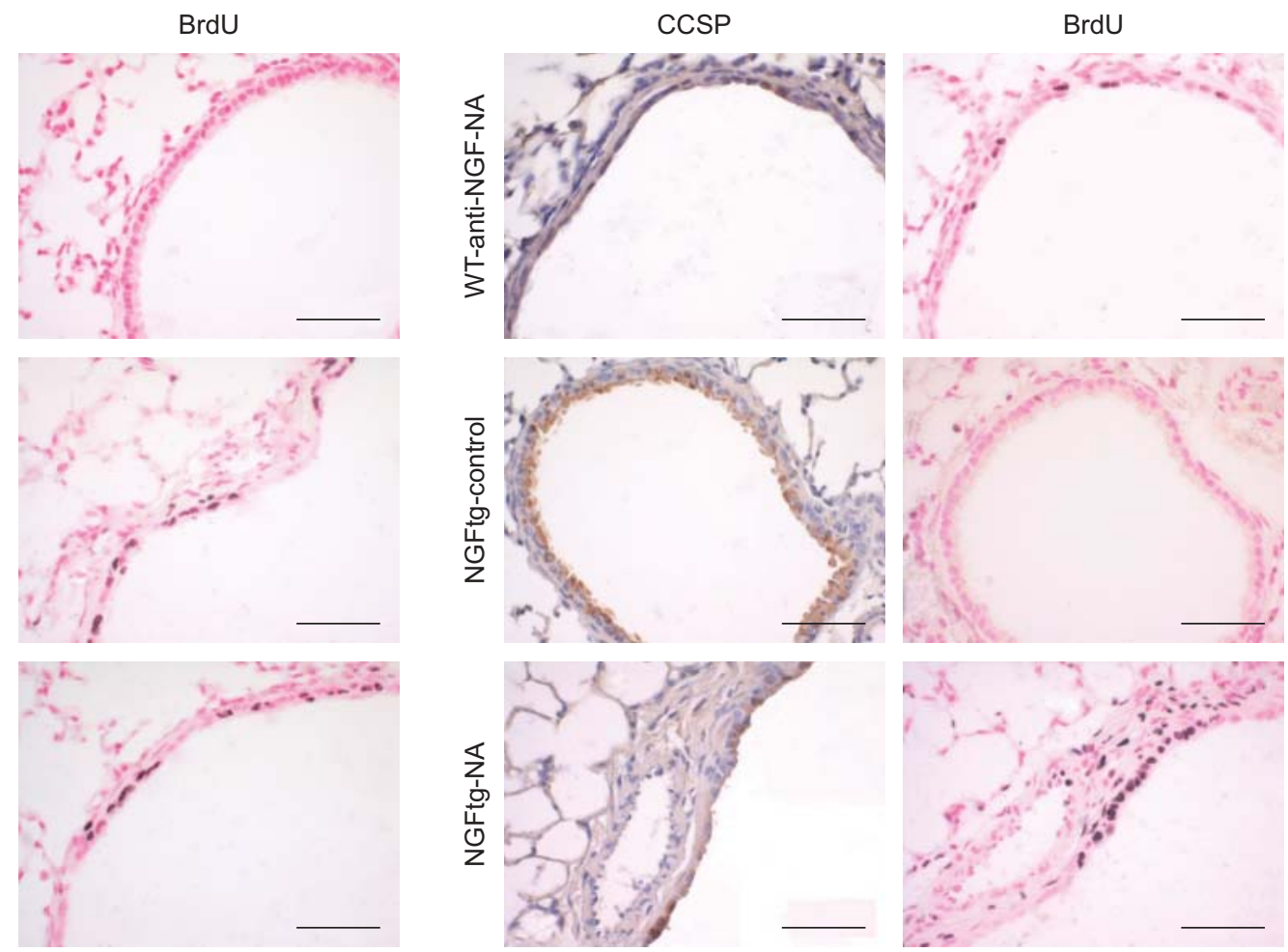

FIGURE 7. Analysis of proliferation by BrdU (5-bromo-2'-deoxy-uridine) incorporation in bronchial epithelium. a) Serial sections of wild-type (WT) control (WT-control), naphthalene (NA)-treated WT (WT-NA) with control immunoglobulin (Ig)G (WT-IgG-NA) or with anti-nerve growth factor (NGF) (WT-anti-NGF-NA) and NGFtg control (NGFtg-control) and NA treated NGFtg (NGFtg-NA) animals stained for Clara cell secretory protein (CCSP)and BrdU are shown. The CCSPpositive Clara cells are stained brown against the blue counter stain and the BrdUpositive cells exhibit a dark brown nucleus against the nuclear fast red counter stain. All animals treated with NA showed positive nuclear staining for BrdU. Scale bars $=50 \mu \mathrm{m}$. b) Quantification of BrdU positive nuclear profiles per $\mathrm{mm}$ of the basement membrane at day 10 after NA treatment. Data are presented as mean $\pm \operatorname{SEM}(n=6)$ for each group of mice. * $p<0.05$.

lung epithelial cells, especially Clara cells that comprise the predominant airway epithelial cell population lining murine airways.

The contribution of epithelial NGF in wound repair was first investigated in vitro using both a clonal murine lung alveolar type II epithelial cell line (LA4) and primary murine AECII. In vitro experiments with wounded LA4 cell monolayers revealed increased protein expression of NGF and its receptor TrkA upon injury. Furthermore, wound closure was accelerated with NGF supplementation and suppressed upon NGF inhibition. Investigation of primary AECII cells, which also express NGF and TrkA, revealed a chemotactic response of AECII to NGF. AECII cells also responded to NGF by expressing increased collagen I and fibronectin mRNA. Most importantly, in both cell types, NGF was seen to strongly mediate proliferation. We then investigated the pro-proliferative function of NGF in vivo by employing a NA model of Clara cell injury.

We investigated the functional effects of NGF on airway epithelium repair in the lung in vivo by utilising a Clara cellspecific injury model. The complete renewal of Clara cells after NA mediated injury takes 1-3 months. The NA model of epithelial injury was investigated for a 29-day period to assess the role of NGF in lung epithelia repair. For this, we included NGFtg animals that overexpress NGF constitutively under the CCSP promoter in Clara cells. The NGFtg animals express around 155-fold higher NGF levels compared with WT mice. The presence of increased NGF levels under normal conditions caused no alteration in the total numbers of Clara cells or any change in cell phenotype. Furthermore, WT and NGFtg animals revealed similar levels of injury at day 1 demonstrated by comparable numbers of exfoliated Clara cells in both mouse strains (fig. S4 in the supplementary material). The NGFtg animals lost most of the NGF-overexpressing Clara cells upon exfoliation; however, the remaining cells produced significantly higher levels of NGF compared with WT animals, which 
may be associated with the accelerated epithelial repair seen in the NGFtg animals. Following injury of Clara cells, lung NGF levels were increased at day 10 and remained significantly elevated until day 29 post injury in both WT and NGFtg mice, emphasising the importance of NGF in the continuing lung repair processes. This is supported by in vitro findings with wounded lung epithelial cells, where NGF synthesis was observed to be upregulated as early as $6 \mathrm{~h}$ after injury and increased progressively with time. Interestingly, the lack of proliferation observed in uninjured lungs of NGFtg animals indicates that the pro-proliferative function of NGF is limited to regenerative situations. Therefore, Clara cell renewal was, at least in part, dependent on the pro-proliferative function of NGF post injury, where BrdU incorporation in vivo was enhanced in NGFtg animals and could be inhibited by antiNGF antibodies.

The overexpression of NGF in the lungs of NGFtg mice has been previously reported to modulate lung innervation and regulate airway hyperresponsiveness [25]. NGF has been suggested as a potential candidate for airway remodelling in asthma and also reported to induce smooth muscle cell proliferation [40,41], migration and differentiation of fibroblasts [42]. In this study, NGF also appeared to modulate collagen I and fibronectin expression, supported by the observations in vitro in AECII and in vivo in the NA model of Clara cell injury. Collagen I and fibronectin mRNA expression were significantly increased upon incubation of primary AECII with exogenous NGF and similar results were seen in vivo under higher NGF levels in lungs of transgenic animals after injury. Based on these findings we suggest that NGF could potentially modulate ECM expression in other processes involving injury and repair, such as airway remodelling in diseases like asthma, where NGF has been previously implicated. Future investigation of the role of NGF in remodelling and fibrosis may shed further light on mechanisms that turn reparative healing processes to pathological events.

In summary, our findings provide evidence that NGF orchestrates proliferative events during repair of the lung epithelia, promoting the renewal of Clara cells in vivo. Therefore, NGF may be considered as an important autocrine epithelial growth factor governing repair in the bronchial airway. While neurotrophins were originally described as molecules that maintain neuronal outgrowth and survival, there is now growing evidence that they belong to a class of multifunctional signalling molecules, which can also mediate repair and proliferation of lung epithelia.

\section{SUPPORT STATEMENT}

This work was supported, in part, by grants from the Deutsche Forschungsgemeinschaft (Transregio 22, Project A9), and Stiftung für Pathobiochemie und Molekulare Diagnostik, DGKL.

\section{STATEMENT OF INTEREST}

None declared.

\section{ACKNOWLEDGEMENTS}

We thank S. Achenbach, E. Kotte for their excellent technical assistance and $\mathrm{T}$. Rausch for performing the CC10 immunohistochemistry.

\section{REFERENCES}

1 Knight DA, Holgate ST. The airway epithelium: structural and functional properties in health and disease. Respirology 2003; 8: 432-446.

2 Mason RJ. Biology of alveolar type II cells. Respirology 2006; 11: S12-S15.

3 Lee TS, Liu YJ, Tang GJ, et al. Wood smoke extract promotes both apoptosis and proliferation in rat alveolar epithelial type II cells: the role of oxidative stress and heme oxygenase-1. Crit Care Med 2008; 36: 2597-2606.

4 Giangreco A, Reynolds SD, Stripp BR. Terminal bronchioles harbor a unique airway stem cell population that localizes to the bronchoalveolar duct junction. Am J Pathol 2002; 161: 173-182.

5 Reynolds SD, Giangreco A, Power JH, et al. Neuroepithelial bodies of pulmonary airways serve as a reservoir of progenitor cells capable of epithelial regeneration. Am J Pathol 2000; 156: 269-278.

6 Boers JE, Ambergen AW, Thunnissen FB. Number and proliferation of clara cells in normal human airway epithelium. Am J Respir Crit Care Med 1999; 159: 1585-1591.

7 Zahm JM, Chevillard M, Puchelle E. Wound repair of human surface respiratory epithelium. Am J Respir Cell Mol Biol 1991; 5: 242-248.

8 Atkinson JJ, Adair-Kirk TL, Kelley DG, et al. Clara cell adhesion and migration to extracellular matrix. Respir Res 2008; 9: 1.

9 Buckpitt AR, Castagnoli N Jr, Nelson SD, et al. Stereoselectivity of naphthalene epoxidation by mouse, rat, and hamster pulmonary, hepatic, and renal microsomal enzymes. Drug Metab Dispos 1987; 15: 491-498.

10 Plopper CG, Suverkropp C, Morin D, et al. Relationship of cytochrome P-450 activity to Clara cell cytotoxicity. I. Histopathologic comparison of the respiratory tract of mice, rats and hamsters after parenteral administration of naphthalene. J Pharmacol Exp Ther 1992; 261: 353-363.

11 Van Winkle LS, Buckpitt AR, Nishio SJ, et al. Cellular response in naphthalene-induced Clara cell injury and bronchiolar epithelial repair in mice. Am J Physiol 1995; 269: L800-L818.

12 Takizawa H, Beckmann JD, Shoji S, et al. Pulmonary macrophages can stimulate cell growth of bovine bronchial epithelial cells. Am J Respir Cell Mol Biol 1990; 2: 245-255.

13 Lewin GR, Barde YA. Physiology of the neurotrophins. Annu Rev Neurosci 1996; 19: 289-317.

14 Freund-Michel V, Frossard N. The nerve growth factor and its receptors in airway inflammatory diseases. Pharmacol Ther 2008; 117: 52-76.

15 Raap U, Fokkens W, Bruder M, et al. Modulation of neurotrophin and neurotrophin receptor expression in nasal mucosa after nasal allergen provocation in allergic rhinitis. Allergy 2008; 63: 468-475.

16 Path G, Braun A, Meents N, et al. Augmentation of allergic earlyphase reaction by nerve growth factor. Am J Respir Crit Care Med 2002; 166: 818-826.

17 Hahn C, Islamian AP, Renz H, et al. Airway epithelial cells produce neurotrophins and promote the survival of eosinophils during allergic airway inflammation. J Allergy Clin Immunol 2006; 117: 787-794.

18 Stanzel RD, Lourenssen S, Blennerhassett MG. Inflammation causes expression of NGF in epithelial cells of the rat colon. Exp Neurol 2008; 211: 203-213.

19 Marinova TS, Markova M, Aloe L. NGF overexpression and distribution in cortical thymic epithelial cells of mice with experimentally-induced leukemia. In Vivo 2006; 20: 259-264.

20 Hayashi K, Storesund T, Schreurs O, et al. Nerve growth factor $\beta$ / pro-nerve growth factor and their receptors in normal human oral mucosa. Eur J Oral Sci 2007; 115: 344-354.

21 Gigliozzi A, Alpini G, Baroni GS, et al. Nerve growth factor modulates the proliferative capacity of the intrahepatic biliary epithelium in experimental cholestasis. Gastroenterology 2004; 127: 1198-1209. 
22 Muangman P, Muffley LA, Anthony JP, et al. Nerve growth factor accelerates wound healing in diabetic mice. Wound Repair Regen 2004; 12: 44-52.

23 Cellini M, Bendo E, Bravetti GO, et al. The use of nerve growth factor in surgical wound healing of the cornea. Ophthalmic Res 2006; 38: 177-181.

24 Nithya M, Suguna L, Rose C. The effect of nerve growth factor on the early responses during the process of wound healing. Biochim Biophys Acta 2003; 1620: 25-31.

25 Hoyle GW, Graham RM, Finkelstein JB, et al. Hyperinnervation of the airways in transgenic mice overexpressing nerve growth factor. Am J Respir Cell Mol Biol 1998; 18: 149-157.

26 Society for Laboratory Animal Sciences. The guidelines for the care and use of experimental animals. Biberach an der Riss, GV-SOLAS, 1988.

27 Yildirim AO, Bulau P, Zakrzewicz D, et al. Increased protein arginine methylation in chronic hypoxia: role of protein arginine methyltransferases. Am J Respir Cell Mol Biol 2006; 35: 436-443.

28 Sel S, Wegmann M, Dicke T, et al. Effective prevention and therapy of experimental allergic asthma using a GATA-3-specific DNAzyme. J Allergy Clin Immunol 2008; 121: 910-916.

29 Weibel ER, Hsia CC, Ochs M. How much is there really? Why stereology is essential in lung morphometry. J Appl Physiol 2007; 102: 459-467.

30 Stevens TP, McBride JT, Peake JL, et al. Cell proliferation contributes to PNEC hyperplasia after acute airway injury. Am J Physiol 1997; 272: L486-L493.

31 Nockher WA, Renz H. Neurotrophins in allergic diseases: from neuronal growth factors to intercellular signaling molecules. J Allergy Clin Immunol 2006; 117: 583-589.

32 Lommatzsch M, Braun A, Mannsfeldt A, et al. Abundant production of brain-derived neurotrophic factor by adult visceral epithelia. Implications for paracrine and target-derived Neurotrophic functions. Am J Pathol 1999; 155: 1183-1193.
33 Frossard N, Naline E, Olgart HC, et al. Nerve growth factor is released by IL-1 $\beta$ and induces hyperresponsiveness of the human isolated bronchus. Eur Respir J 2005; 26: 15-20.

34 Tortorolo L, Langer A, Polidori G, et al. Neurotrophin overexpression in lower airways of infants with respiratory syncytial virus infection. Am J Respir Crit Care Med 2005; 172: 233-237.

35 Ricci A, Graziano P, Bronzetti E, et al. Increased pulmonary neurotrophin protein expression in idiopathic interstitial pneumonias. Sarcoidosis Vasc Diffuse Lung Dis 2007; 24: 13-23.

36 Matsuda $\mathrm{H}$, Koyama $\mathrm{H}$, Sato $\mathrm{H}$, et al. Role of nerve growth factor in cutaneous wound healing: accelerating effects in normal and healing-impaired diabetic mice. J Exp Med 1998; 187: 297-306.

37 Matsuda H, Koyama H, Sato $\mathrm{H}$, et al. Role of nerve growth factor in cutaneous wound healing: accelerating effects in normal and healing-impaired diabetic mice. J Exp Med 1998; 187: 297-306.

38 Lambiase A, Manni L, Bonini S, et al. Nerve growth factor promotes corneal healing: structural, biochemical, and molecular analyses of rat and human corneas. Invest Ophthalmol Vis Sci 2000; 41: 1063-1069.

39 Holgate ST, Lackie P, Wilson S, et al. Bronchial epithelium as a key regulator of airway allergen sensitization and remodeling in asthma. Am J Respir Crit Care Med 2000; 162: S113-S117.

40 Dagnell C, Kemi C, Klominek J, et al. Effects of neurotrophins on human bronchial smooth muscle cell migration and matrix metalloproteinase-9 secretion. Transl Res 2007; 150: 303-310.

41 Freund-Michel V, Bertrand C, Frossard N. TrkA signalling pathways in human airway smooth muscle cell proliferation. Cell Signal 2006; 18: 621-627.

42 Micera A, Vigneti E, Pickholtz D, et al. Nerve growth factor displays stimulatory effects on human skin and lung fibroblasts, demonstrating a direct role for this factor in tissue repair. Proc Natl Acad Sci USA 2001; 98: 6162-6167. 